\title{
Vermicomposting under High Altitude Cold Arid Ladakh (Kargil) Conditions: A Success Story
}

\author{
Malik Asif Aziz ${ }^{1 *}$, M.Y. Zargar², M.A. Malik ${ }^{1}$, Z.M. Dar ${ }^{1}$, Aamir H. Mir ${ }^{3}$, \\ M. Amjad ${ }^{4}$, Shakeel A. Mir ${ }^{3}$, Misbah Ajaz ${ }^{1}$, Saima Shafi ${ }^{1}$ and Bisma Rashid ${ }^{1}$ \\ ${ }^{1}$ Division of Basic Sciences and Humanities, FoA /RRS, Sher-e-Kashmir University of \\ Agricultural Sciences and Technology of Kashmir, Wadura -193201, India \\ ${ }^{2}$ Directorate of Research, Shalimar Campus, Srinagar, India \\ ${ }^{3}$ Division of Soil Sciences, ${ }^{4}$ Division of Agronomy, FoA /RRS, Wadura, Sher-e-Kashmir \\ University of Agricultural Sciences and Technology of Kashmir, Wadura -193201, India \\ *Corresponding author
}

\section{A B S T R A C T}

\begin{tabular}{|l|}
\hline Ke y w or d s \\
Kargil, \\
Vermicompost, \\
Success story, \\
Earth worms \\
\hline Article Info \\
\hline $\begin{array}{l}\text { Accepted: } \\
\text { 19 July 2017 } \\
\text { Available Online: } \\
\text { 10 September 2017 }\end{array}$ \\
\hline
\end{tabular}

The present study was carried out under cold arid conditions of Kargil district of Ladakh region. The area receives very scanty rainfall and most of the precipitation is witnessed in the form of snow during harsh winter period. The farmers are marginal and resource poor. Chemical fertilizers are not available during the peak growing season because of continuous road closure for at least five months. The only alternative available with the farmers is use of night soil and undecomposed cowdung in the area. But most of the crops in the area are showing nutrient deficiency and disease outbreak. Therefore the available resources were utilized by employing some exotic earthworms viz., Eisenia foetida for speedy conversion into valuable product i.e. vermicompost. The technology was successfully disseminated in the farmers' field through conduction of on farm and off farm training programmes. Few progressive farmers have started their own vermicompost units at commercial scale.

\section{Introduction}

Of late, much emphasis has been paid globally on organic farming with large-scale use of organic manures and biofertilizers. Organic farming has emerged as an important priority area globally in view of the growing demand for safe and healthy food and long term sustainability and concerns on environmental pollution associated with indiscriminate use of agrochemicals. The essential concept of organic farming remains the same, i.e., back to nature, where the philosophy is to feed the soil rather than the crops to maintain soil health. Kargil a cold arid region with extreme climatic conditions remains cut off for at least six months from rest of the world. Acute shortage of synthetic fertilizers like urea, DAP, MOP etc during the peak growing season in the region necessitates the exploitation of other sources of fertilizers. The farmers are now mainly 
using the organic manures and the area is organic by default since ancient times because of the unavailability of synthetic fertilizers during the onset of growing season and the poor condition of the farming community.

The concept of vermicompost technology in the region has not received due attention during the past. The success of composting depends upon the fecundit of the earthworm. It has the efficiency to consume all types of organic rich waste material including vegetable wastes, industrial, dairy farm wastes, garden waste, sugar mill residues, slaughter house waste, hatcher waste and municipal wastes (Zambare et al., 2008). The protocol for production of vermicompost from different sources of raw materials has been developed recently at Krishi Vigyan Kendra (KVK), Kargil, SKUAST-Kashmir. Three exotic earthworm species have been identified for efficient vermicomposting but out of these three species, Eisenia foetida has an outstanding performance in the area. The earthworms are multiplied and provided to farmers in the entire region for producing vermicompost. Until now 45000 earthworms have been provided to the farmers and other clients.

\section{Production technology}

\section{Raw materials required}

Cow dung and any other biodegradable waste such as crop residues, leaf litter, weed biomass, vegetable wastes, slaughter house waste, bio-degradable portion of urban and rural wastes etc. may be used for the preparation of vermicompost.

\section{Earthworm species suitable for vermicompost production}

The following earthworm species may be used for preparation of vermicompost
Eisenia foetida (Efficient one)

Eudrilus eugeniae

Perionyx excavatus

\section{Methods of preparation}

The Vermicompost can be prepared in locally made pits.

The standard size of the pits should be $8 \times 3 \times$ $3 \mathrm{ft}(1 \times \mathrm{b} \times \mathrm{d})$.

The available bio-wastes are to be collected and are to be heaped under sun for about 1015 days and covered with a shade net.

Sprinkling of cow dung slurry to the heap may be done.

A thin layer of half decomposed cow dung (12 inches) is to be placed at the bottom.

Place the chopped weed biomass and partially decomposed cow dung layer wise $(10-20 \mathrm{~cm})$ in the pits upto the depth of $3 \mathrm{ft}$.

The bio waste and cow dung ratio should be 60: 40 on dry wt. basis.

Release about 2-3 kg earthworms per pit.

Place wire net / shade net over the pits to protect earthworm from birds

Sprinkling of water should be done to maintain $70-80 \%$ moisture content.

Turning of bio-waste material should be done at an interval of 25 days.

Provision of a shed over the compost is essential to prevent entry of rainwater, snow and direct sunshine.

Sprinkling of water should be stopped when $90 \%$ bio-wastes are decomposed. Maturity 
could be judged visually by observing the formation of granular structure of the compost at the surface of the pit.

Harvest the Vermicompost by scrapping layer wise from the top of the pit and heap under shed. This will help in separation of earthworms from the compost. Sieving may also be done to separate the earthworms and cocoons.

\section{Separation of earthworms and cocoon}

Heap the harvested vermicompost for 6-12 hours under shade for separation of the earthworm.

Sieve vermicompost for separation of baby earthworm and cocoons.

Dry vermicompost (if necessary) under shade to keep the moisture content below 20 per cent.

Separate earthworms and cocoons for reuse.

\section{Protection from enemies}

Bio-wastes free from ants /termites etc are to be used for vermicompost preparation.

The vermicompost thus prepared would normally have the nutrients of following concentrations (Table 1).

\section{Advantages of vermicompost}

Vermicompost is a rich source of vitamins, hormones, enzymes, macro and micronutrients which when applied to plants help in efficient growth (Prabakaran, 2005)

The vermiculture provides for the use of earthworms as natural bioreactors for costeffective and eco friendly waste management (Aalok et al., 2008).
Provides excellent effect on overall plant growth, encourages new shoots/ leaves and improves the quality and self-life of the produce.

Vermicompost is free flowing, easy to handle, store and apply and does not have bad odour.

Earthworms change the soil in many beneficial ways. They increase the soil's plant available nutrient content (example: nitrates, phosphates, exchangeable calcium and soluble potassium), growth regulators and useful bacterial populations (Bhadauria and Ramakrishnan, 1996).

Improves soil structure, texture, aeration, water holding capacity and prevents soil erosion.

Vermicompost is rich in beneficial microflora such as $\mathrm{N}$ fixers, P-solubilizers, cellulose decomposing micro-flora etc (Table 2).

The digestive enzymes of earthworm are responsible for the decomposition and humification of organic matter. These enzymes are active at a very narrow $\mathrm{pH}$ range and efficiently maintain the non - linear $\mathrm{pH}$ parameters (Gajalakshmi and Abbasi, 2003) Vermicompost is rich in several enzymes and growth regulators such as auxins, gibberellins etc.

Vermicompost contains earthworm cocoons and increases the population and activity of earthworm in soil.

Prevents nutrient losses and increase the use efficiency of chemical fertilizers.

Vermicompost is free from pathogens, toxic elements, weed seeds etc.

Availability of nutrients from vermicompost is faster due to its narrow $\mathrm{C}$ : $\mathrm{N}$ ratio 
Vermicompost minimizes the incidences of pests and diseases in crop.
Vermicompost enhances the decomposition of organic matter in soil.

Table.1 Protection from enemies

\begin{tabular}{|l|l|}
\hline Nutrients & In percent $(\%)$ \\
\hline Nitrogen & 1.9 \\
\hline Phosphorus & 1.18 \\
\hline Potassium & 1.88 \\
\hline Calcium & $0.5-1.0$ \\
\hline Magnesium & $0.2-0.3$ \\
\hline Sulphur & $0.4-0.5$ \\
\hline Iron & $0.8-1.5$ \\
\hline Copper $(\mathrm{ppm})$ & 18 \\
\hline Zinc $(\mathrm{ppm})$ & 100 \\
\hline
\end{tabular}

Table.2 Nutritional composition of vermicompost and conventional compost

\begin{tabular}{|l|l|l|}
\hline Nutrient element & Vermicompost & Conventional Compost \\
\hline Nitrogen $(\%)$ & 1.9 & 0.64 \\
\hline Phosphorus $\left(\mathrm{P}_{2} \mathrm{O}_{5}\right)(\%)$ & 1.18 & 0.88 \\
\hline Potassium $\left(\mathrm{K}_{2} \mathrm{O}\right)(\%)$ & 1.88 & 0.72 \\
\hline Total Organic carbon & 27.2 & 28.0 \\
\hline Water soluble carbon & 0.88 & 1.60 \\
\hline Zinc $(\mathrm{ppm})$ & 100 & 80 \\
\hline Copper $(\mathrm{ppm})$ & 18 & 14 \\
\hline C:N ratio & 13.60 & 20.60 \\
\hline Moisture Content $(\%)$ & 46.5 & 41.5 \\
\hline
\end{tabular}

Table.3 Trainings imparted

\begin{tabular}{|l|l|l|l|}
\hline $\begin{array}{l}\text { S. } \\
\text { No }\end{array}$ & Title of Training & $\begin{array}{l}\text { No. } \\
\text { Beneficiaries }\end{array}$ & Target Group \\
\hline 1 & $\begin{array}{l}\text { Vermicompost: } \\
\text { preparation and } \\
\text { application }\end{array}$ & 1400 & Farm women, rural youth, allied departments \\
\hline 2 & $\begin{array}{l}\text { Demonstration on } \\
\text { Vermicompost } \\
\text { Technology }\end{array}$ & 100 & Farmers/farm women/rural youth and extension functionaries \\
\hline 3 & Advisory Service & 567 & Farmers and officials of line departments \\
\hline 4 & TV/Radio Talks & 3000 & Farmers/rural youth and extension functionaries \\
\hline
\end{tabular}


Fig.1 On and off farm training programmes imparted to extension functionaries and farm women in kargil
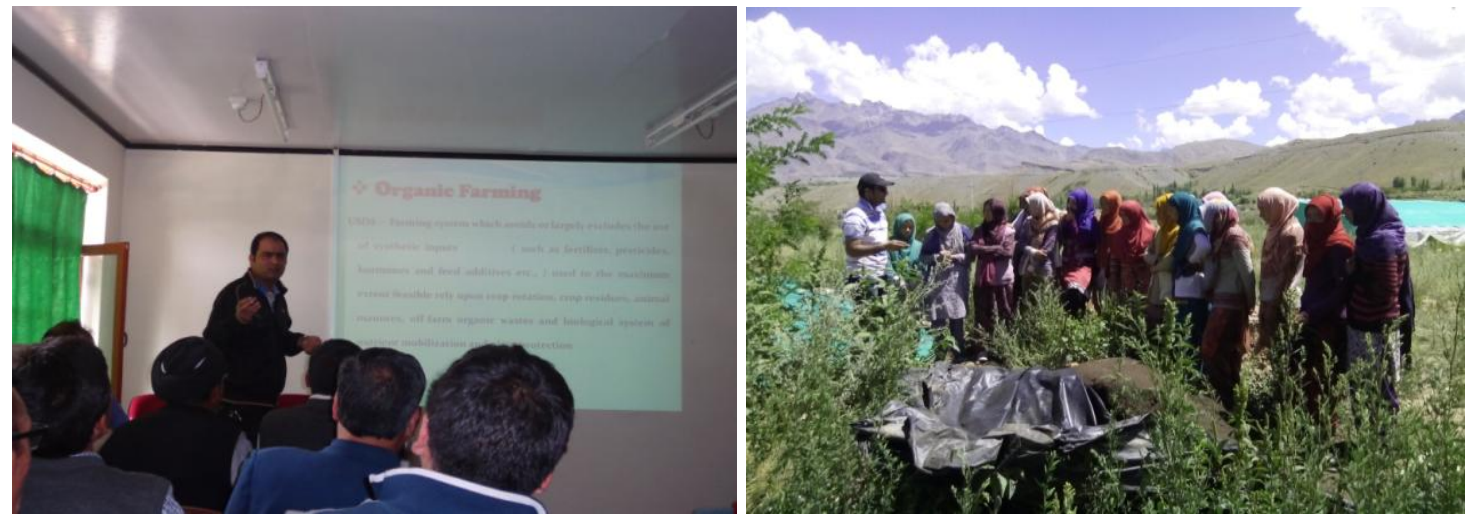

Fig.2 Future thrust

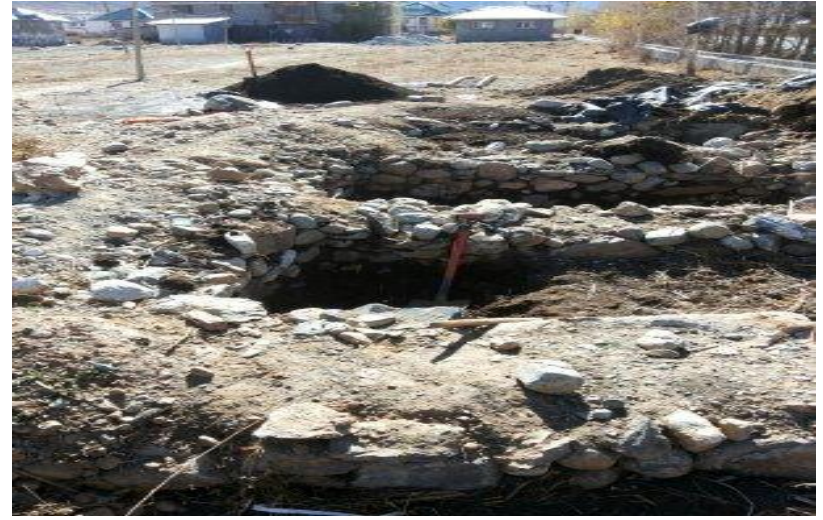

View of Vermicompost Demonstration Unit

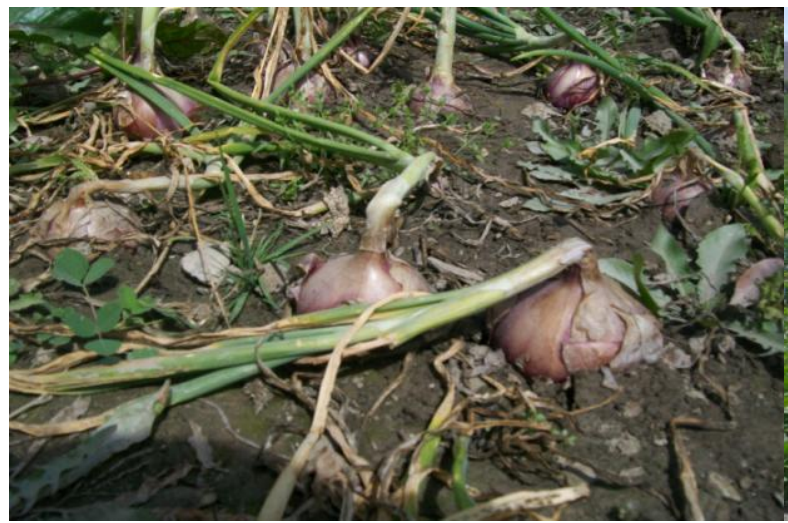

$50 \% \mathrm{~N}$ substitution through

Vermicompost in Onion

\section{Technology transfer}

The technology of production of vermicompost from cowdung and sheep manure is being provided to the farmers/farm women/rural

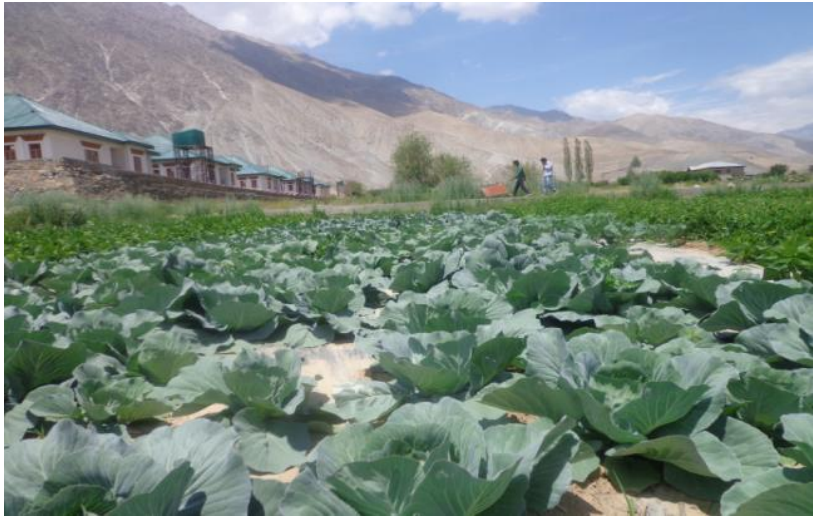

$75 \%$ N Substitution through

Vermicompost in Cabbage

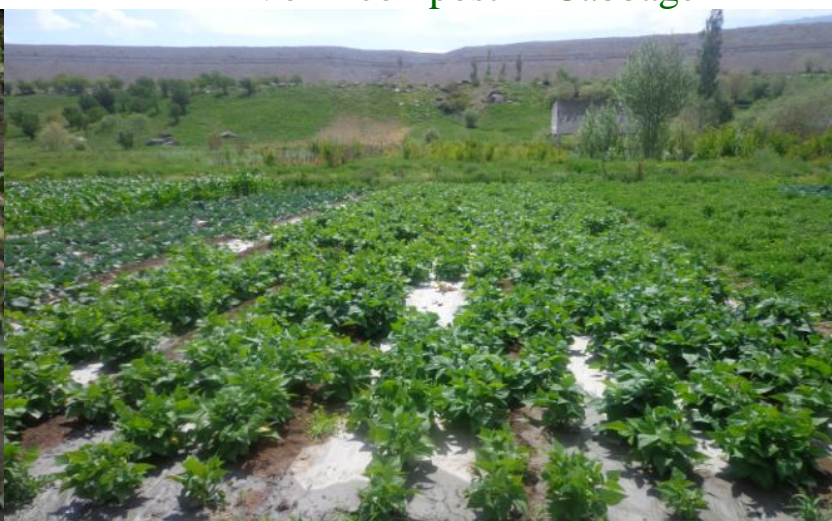

$70 \% \mathrm{~N}$ substitution through

Vermicompost in French bean

youth of the region by providing on and off farm trainings and demonstrations. More than 1500 farmers/farm women/ extension functionaries have received trainings so far (Fig. 1). The advisory service is also being 
provided to the farmers and officers of the line departments from time to time. Experiences for last few years showed that there is vast potentiality of utilizing animal manure and agriculture biomass for production of vermicompost in Kargil (Table 3). Further, the time taken for production of vermicompost is only 60-70 days during summers.

\section{Technology adoption}

The technology of vermicompost production from organic manures and other agriculture biomass has been well accepted by the farming community and already small units of vermicompost production have become popular in different parts of the district.

The commercial aspect of producing vermicompost from agricultural biomass shows great promise. Already few progressive farmers which were more interested have started their own units of commercial production of vermicompost. The vermicompost thus produced has good demand particularly among the vegetable growers.

Further department of Sheep Husbandry Kargil have also started large scale production of vermicompost with the technology received from Krishi Vigyan Kendra (KVK), Kargil, SKUAST-K

\section{Future thrust}

The technology of utilizing agricultural waste/biomass for production of Vermicompost needs to be popularized among the farming community of kargil (Fig. 2).

For this purpose, extensive trainings are required to be provided to the farming community of the entire region.

Establishment of a demonstration unit in every village of the region will definitely help in popularizing the technology among the farmers.

\section{References}

Aalok, A., Tripathi A.K and Soni. P. 2008. Vermicomposting: A better solution for organic solid waste management. Journal of Human Ecology. 24, 59- 64

Bhadauria, T., and Ramakrishnan, P.S. 1996. Population Dynamics of earthworms and their activity in forest ecosystems of North- East. Journal of Tropical Ecology.7: 305- 318.

Gajalakshmi, S., and Abbasi, S.A.2003. High rate vermicomposting systems for recycling paper waste. Indian Journal of Biotechnology. 2: 613- 615.

Prabakaran, J., 2005. Biomass resources in vermicomposting, In: proceedings of the State Level Symposium on Vermicomposting Technology for Rural Development, Madurai, Tamil Nadu, India. 27- 40.

Zambare, V.P., Padul, M.V., Yadav, A.A. and Shete. T.B.2008. Biochemical and Microbiological approach as ecofriendly soil conditioner. Journal of Agricultural and Biological Sciences. 3: 1- 4.

\section{How to cite this article:}

Malik Asif Aziz, M.Y. Zargar, M.A. Malik, Z.M. Dar, Aamir H. Mir, M. Amjad, Shakeel A. Mir, Misbah Ajaz, Saima Shafi, and Bisma Rashid. 2017. Vermicomposting under High Altitude Cold Arid Ladakh (Kargil) Conditions: A Success Story. Int.J.Curr.Microbiol.App.Sci. 6(9): 1579-1584. doi: https://doi.org/10.20546/ijcmas.2017.609.194 